\title{
Effect of a supplement containing trans-10,cis-12 conjugated linoleic acid on the performance of dairy ewes fed 2 levels of metabolizable protein and at a restricted energy intake
}

\author{
W. M. P. B. Weerasinghe, ${ }^{\star 1}$ R. G. Wilkinson, ${ }^{\star}$ A. L. Lock, $†$ M. J. de Veth,$\neq^{2}$ D. E. Bauman, $\S$ and L. A. Sinclair ${ }^{\star 3}$ \\ *Harper Adams University College, Newport, Shropshire, TF10 8NB, United Kingdom \\ †Department of Animal Science, Michigan State University, East Lansing 48824 \\ łBASF AG, 67056 Ludwigshafen, Germany \\ §Department of Animal Science, Cornell University, Ithaca, NY 14853
}

\begin{abstract}
Trans-10,cis-12 conjugated linoleic acid (CLA) inhibits milk fat synthesis in dairy ewes, but the effects under varying dietary metabolizable protein (MP) levels when energy-limited diets are fed have not been examined. The objectives of the study were to evaluate the response of lactating dairy ewes to CLA supplementation when fed diets limited in metabolizable energy (ME) and with either a low or high MP content. Twelve multiparous ewes in early lactation were randomly allocated to 1 of 4 dietary treatments: a high MP ( $110 \%$ of daily MP requirement) or low MP (93\% of daily MP requirement) diet unsupplemented or supplemented with a lipid-encapsulated CLA to provide $2.4 \mathrm{~g} / \mathrm{d}$ of trans-10,cis-12 CLA, in each of 4 periods of $25 \mathrm{~d}$ each in a $4 \times 4$ Latin square design. All diets were restricted to supply each ewe with $4.6 \mathrm{Mcal}$ of ME/d (equivalent to $75 \%$ of ME requirement). Supplementation with CLA decreased milk fat percentage and yield by $33 \%$ and $24 \%$, respectively, and increased milk, milk protein, and lactose yields by 16,13 , and $17 \%$, respectively. Feeding the high MP diet increased the yields of milk, fat, protein, and lactose by $18,15,19$, and $16 \%$, respectively. Milk fat content of trans-10, cis-12 CLA (g/100 g) was 0.09 and $<0.01$ for the CLA-supplemented and unsupplemented ewes, respectively. Ewes supplemented with CLA had a reduced yield $(\mathrm{mmol} / \mathrm{d})$ of fatty acids of $<\mathrm{C} 16, \mathrm{C} 16$, and $>\mathrm{C} 16$, although the effect was greatest for $<\mathrm{C} 16$. Feeding a high MP level increased the yield of fatty acids of $\mathrm{C} 16$ and $>\mathrm{C} 16$. Plasma urea concentrations were lowest in ewes supplemented with CLA compared with those unsupplemented (6.5 vs.
\end{abstract}

\footnotetext{
Received January 11, 2011.

Accepted September 6, 2011.

${ }^{1}$ Present address: Veterinary Research Institute, Gannoruwa, Peradeniya, Sri Lanka.

${ }^{2}$ Present address: Department of Animal Science, The University of Tennessee, Knoxville 37996.

${ }^{3}$ Corresponding author: lsinclair@harper-adams.ac.uk
}

$7.4 \mathrm{mmol} / \mathrm{L}$, respectively) and receiving low compared with high MP diets (5.6 vs. $8.3 \mathrm{mmol} / \mathrm{L}$, respectively). In conclusion, dairy ewes fed energy-limited diets and supplemented with CLA repartitioned nutrients to increase yields of milk, protein, and lactose, with the response to CLA supplementation and additional MP intake being additive.

Key words: conjugated linoleic acid, metabolizable protein, milk fat depression, sheep

\section{INTRODUCTION}

Conjugated linoleic acids (CLA) represent different positional and geometric configurations of octadecadienoic acids containing a pair of double bonds in a conjugated configuration (Bauman and Griinari, 2003). Numerous studies have concluded that trans-10, cis-12 CLA is a potent inhibitor of milk fat synthesis in dairy cows (Bauman et al., 2008), although other isomers such as trans-9,cis-11 CLA and cis-10,trans-12 CLA have also been demonstrated to have potent milk fat depression effects in dairy cows (Saebø et al., 2005; Perfield et al., 2007). Feeding ruminally protected sources containing trans-10,cis-12 CLA has consistently been shown to reduce milk fat synthesis in dairy ewes (Lock et al., 2006; Sinclair et al., 2007, 2010). This effect occurs rapidly and in a dose-dependent manner without any detrimental effect on body organ weight or liver lipid content (Sinclair et al., 2010).

In some studies, supplementing dairy ewes with a ruminally protected source of trans-10,cis-12 CLA has been associated with increases in milk and milk protein yields (Lock et al., 2006; Husvéth et al., 2010; Sinclair et al., 2010). In contrast, Sinclair et al. (2007) reported no significant effect of trans-10, cis-12 CLA supplementation on milk performance although supplemented animals were calculated to be in a greater positive energy balance (EBAL). Similarly, a production response has not always been observed in dairy cows following abomasal infusion or feeding of protected sources of 
trans-10, cis-12 CLA. However, under situations in which energy supply was limiting, such as occurs in early lactation (Bernal-Santos et al., 2003; de Veth et al., 2005), or when dietary energy supply was restricted (de Veth et al., 2006), the energy spared by CLA-induced milk fat depression (MFD) appeared to be repartitioned to allow increases in the synthesis of milk protein and lactose. Supplementation with trans-10,cis-12 CLA has also been associated with an increase in milk and milk protein yield in cows that are grazing pasture (Mackle et al., 2003; Kay et al., 2006; Medeiros et al., 2010). Grazing pasture characteristically results in a limited energy intake but is usually accompanied by an excess supply of MP (Kolver and Muller, 1998). Newbold (1994) suggested that ruminants attempt to maintain an optimum MP:ME ratio and that additional dietary MP may result in a greater requirement for ME, which can be obtained by increasing dietary intake, by the use of protein as an energy source, or by mobilization of body energy reserves. A reduction in ME requirement for milk synthesis due to trans-10,cis-12 CLA-induced MFD potentially provides a fourth source of ME to the lactating animal that may be used to increase milk production. The objectives of the study were to examine the effects of trans-10,cis-12 CLA supplementation and dietary MP supply on milk fat synthesis and milk and milk protein yields in dairy ewes fed at a restricted level of ME intake. Thus, the MP and energy levels were chosen to allow comparisons that would approximate the nutritional status of ewes in early lactation or ewes fed in a pasture-based system.

\section{MATERIALS AND METHODS}

\section{Animals, Management, and Treatments}

All procedures involving animals were conducted in accordance with the UK Animals (Scientific Procedures) Act 1986. Twelve multiparous ewes were grouped immediately postlambing, housed on straw, and fed a standard ewe concentrate at the daily rate of $1.5 \mathrm{~kg}$ /ewe in 3 meals at 0800,1300 , and $1600 \mathrm{~h}$, with grass hay (Lolium perenne) being offered ad libitum. Lambs were weaned from the ewes at 4 wk postpartum; the ewes were shorn, individually penned, bedded on sawdust, and milked twice daily at 0800 and 1530 $\mathrm{h}$ through a standard ewe milking parlor. In wk 5 of lactation the ewes were randomly allocated to 1 of 4 dietary treatments, based on their milk and constituent yield, live weight, and BCS (Russell et al., 1969) in the week before allocation.

The ewes were fed 1 of 4 complete diets containing grass hay (Lolium perenne), which was chopped to a mean length of $19 \mathrm{~mm}$, and concentrate (0.45:0.55 DM basis; Table 1). The diets were weighed daily for each animal and offered immediately after milking at 0830 h. Feed intake for each ewe was restricted to $1.8 \mathrm{~kg}$ of $\mathrm{DM} / \mathrm{d}$, predicted to supply 4.6 Mcal of ME/d, which is approximately $75 \%$ of ad libitum intake (AFRC, 1993). The high MP diet was predicted to supply $110 \%$ of daily MP requirements $(190 \mathrm{~g} / \mathrm{d})$, whereas the low MP diet was predicted to supply $93 \%$ of requirements (161 g/d) calculated according to AFRC (1993). These levels were chosen to supply either excess amounts of MP to resemble a pasture-based system or moderate amounts of MP for milk production to replicate ewes in early lactation, and are similar to the 117 and $88 \%$ of MP requirements used in dairy cows by de Veth et al. (2006). The diets were either unsupplemented or supplemented with a lipid-encapsulated CLA product that contained 2 CLA isomers in equal proportions, cis-9,trans-11 and trans-10,cis-12 (Lutrell, BASF SE, Ludwigshafen, Germany). The supplement $(25 \mathrm{~g} / \mathrm{d})$ provided $2.4 \mathrm{~g}$ of trans-10,cis-12 CLA/d. The formulation and general characteristics of the lipid-encapsulated CLA product have been described previously (Lock et al., 2006), and the FA composition is given in a footnote to Table 1. The 4 treatment diets were therefore as follows: low MP - CLA, high MP - CLA, low MP + CLA, and high MP + CLA. The experimental design was a 4 $\times 4$ Latin square with 25 -d experimental periods; the first $20 \mathrm{~d}$ represented an adaptation period followed by a 5 -d sampling period. Feed samples were collected weekly throughout the experiment, stored at $-20^{\circ} \mathrm{C}$, and composited before analysis. During the sampling period, milk yield was recorded daily at each milking and samples collected for analysis of fat, protein, and lactose. On the last sampling day of each period, an additional milk sample was collected and stored at $-20^{\circ} \mathrm{C}$ for subsequent fatty acid (FA) analysis. On d 23 of each period, blood was sampled from the jugular vein 3 times $(0730,1130$, and $1430 \mathrm{~h})$ into evacuated tubes containing either lithium heparin or potassium oxalate, and the plasma was separated for subsequent analysis of urea, BHBA, and glucose. Ewe BW and BCS were measured at the start of the study and end of each period.

\section{Chemical Analysis}

Feed and milk samples were analyzed as described by Lock et al. (2006). Extraction of milk fat was performed according to the method by Hara and Radin (1978). Fatty acid methyl esters were prepared by base-catalyzed transmethylation according to Christie (1982) as modified by Chouinard et al. (1999). FA methyl esters were then injected into a gas chromatograph (Agilent 6890, Agilent Technologies UK Ltd., Berkshire, UK) 
Table 1. Ingredients, predicted and determined chemical composition, and selected fatty acid (FA) profile of the experimental diets

\begin{tabular}{|c|c|c|}
\hline \multirow[b]{2}{*}{ Item } & \multicolumn{2}{|c|}{ Diet } \\
\hline & Low MP & High MP \\
\hline \multicolumn{3}{|l|}{ Ingredient, $\mathrm{g} / \mathrm{kg}$ of $\mathrm{DM}^{1}$} \\
\hline Hay (Lolium perenne) & 450 & 450 \\
\hline Barley (rolled) & 235 & 169 \\
\hline Molassed sugar beet pulp ${ }^{2}$ & 235 & 169 \\
\hline Rapeseed meal & 13.2 & 67.1 \\
\hline Corn gluten meal & - & 27.5 \\
\hline Soybean meal & - & 39.6 \\
\hline Megalac $^{3}$ & 17.6 & 13.2 \\
\hline Sopralin ${ }^{4}$ & - & 27.5 \\
\hline Urea & 14.9 & 3.3 \\
\hline Molasses & 19.2 & 19.2 \\
\hline Minerals and vitamins ${ }^{5}$ & 14.3 & 14.3 \\
\hline \multicolumn{3}{|l|}{ Predicted analysis $^{6}$} \\
\hline ERDP, $\mathrm{g} / \mathrm{kg}$ of DM & 100 & 99 \\
\hline DUP, $\mathrm{g} / \mathrm{kg}$ of DM & 26 & 42 \\
\hline $\mathrm{MP}, \mathrm{g} / \mathrm{kg}$ of DM & 89 & 106 \\
\hline \multicolumn{3}{|l|}{ Chemical analysis } \\
\hline $\mathrm{DM}, \mathrm{g} / \mathrm{kg}$ & 892 & 889 \\
\hline $\mathrm{ME}, \mathrm{Mcal} / \mathrm{kg}$ of DM & 2.6 & 2.6 \\
\hline $\mathrm{CP}, \mathrm{g} / \mathrm{kg}$ of $\mathrm{DM}$ & 155 & 170 \\
\hline $\mathrm{NDF}, \mathrm{g} / \mathrm{kg}$ of DM & 485 & 478 \\
\hline $\mathrm{ADF}, \mathrm{g} / \mathrm{kg}$ of $\mathrm{DM}$ & 281 & 276 \\
\hline \multicolumn{3}{|l|}{ FA profile, $\mathrm{g} / \mathrm{kg}$ of DM } \\
\hline 14:0 & 0.28 & 0.27 \\
\hline $16: 0$ & 10.46 & 9.89 \\
\hline 18:0 & 1.01 & 1.00 \\
\hline 18:1 cis-9 & 7.51 & 7.90 \\
\hline $18: 2$ cis- 9 , cis- 12 & 9.33 & 10.36 \\
\hline $18: 3$ & 2.35 & 2.23 \\
\hline Total & 48.65 & 49.38 \\
\hline
\end{tabular}

${ }^{1}$ Ingredient and chemical composition values do not include the lipidencapsulated conjugated linoleic acid (CLA) supplement, which had a fat content of $80 \%$ (FA composition was $12 \% 16: 0,52 \% 18: 0,9 \%$ cis-9 18:1, $1 \%$ cis-9,cis-12 18:2, 12\% cis-9,trans-11 CLA, and 12\% trans10, cis-12 CLA).

${ }^{2}$ By-product of the manufacture of sugar, consisting of extracted sugar beet slices and sugar beet molasses, which have been dried (Trident Feeds, Peterborough, UK).

${ }^{3} \mathrm{~A}$ rumen-protected fat, combining natural plant oil (palm fatty acids) with calcium (Volac International Ltd., Hertfordshire, UK).

${ }^{4}$ Formaldehyde treated soybean meal (Frank Wright-Trouw Nutrition International, Ashbourne, UK).

${ }^{5}$ Ewe mineral/vitamin premix (SC Feeds, Staffordshire, UK). Major minerals $(\mathrm{g} / \mathrm{kg}$ ) were Ca 245.7, Na 78.6, Mg 50, and P 20; trace minerals $(\mathrm{mg} / \mathrm{kg})$ were $\mathrm{Zn} 4,000$, Fe 4,000, Mn 2,000, I 300, Co 80, and Se 24 ; vitamins $(\mathrm{mg} / \mathrm{kg})$ were retinol 75 , cholecalciferol 1.25, and all rac $\alpha$-tocopherol acetate 4,000 .

${ }^{6} \mathrm{ERDP}=$ effective rumen degradable protein; DUP $=$ digestible undegradable protein; $\mathrm{MP}=$ metabolizable protein, calculated as described by AFRC (1993).

fitted with an automatic sampler, integrator, and flameionization detector and separated using a CP-SIL 88 fused silica capillary column (100 m with $0.2-\mu \mathrm{m}$ film thickness; Varian Ltd., Oxford, UK). Oven temperature was programmed as $70^{\circ} \mathrm{C}$ initial, then increased to $110^{\circ} \mathrm{C}$ at the rate of $8^{\circ} \mathrm{C} / \mathrm{min}$, increased to $170^{\circ} \mathrm{C}$ at the rate of $5^{\circ} \mathrm{C} / \mathrm{min}$, and finally increased to $225^{\circ} \mathrm{C}$ at the rate of $4^{\circ} \mathrm{C} / \mathrm{min}$. Hydrogen was used as a carrier gas and each peak was identified and quantified using pure FA methyl ester standards (Restek, Bellefonte, PA). Yields of glycerol and thereby individual milk FA were calculated as described by Schauff et al. (1992).

Lipids in feed were extracted and the FA methylated and quantified according to Sukhija and Palmquist (1988) with modifications by Loor et al. (2004) using nonadecaenoic acid as an internal standard. Gas chromatography analysis and column conditions were the same as that for milk FA analysis. Plasma samples were analyzed for BHBA, glucose, and urea (Randox Laboratories, County Antrim, UK; kit catalog nos. RB 1007, GL1611, and UR221, respectively), using a Cobas Miras Plus auto analyzer (ABX Diagnostics, Bedfordshire, UK).

\section{Statistical Analysis}

Milk production and composition data were averaged for the 5-d sampling period. Milk production and composition, BW, BCS, and milk FA were analyzed as a 2 $\times 2$ factorial design using Genstat 8 (VSN Int. Ltd., Oxford, UK). The mixed model used was $\mathrm{Y}_{\mathrm{ijk}}=\mu+\mathrm{C}_{\mathrm{i}}$ $+\mathrm{M}_{\mathrm{j}}+\mathrm{C} \cdot \mathrm{M}_{\mathrm{ij}}+\mathrm{P}_{\mathrm{k}}+\mathrm{A}_{1}+\mathrm{E}_{\mathrm{ijkl}}$, where $\mathrm{Y}_{\mathrm{ijk}}$ is observation, $\mu$ is overall mean, $\mathrm{C}_{\mathrm{i}}$ is CLA, $\mathrm{M}_{\mathrm{j}}$ is protein level, $\mathrm{C} \cdot \mathrm{M}_{\mathrm{ij}}$ is the interaction between CLA and protein, $\mathrm{P}_{\mathrm{k}}$ is period, $A_{1}$ is animal, and $E_{\mathrm{ijkl}}$ is the residual error. Of the model components $\mathrm{C}, \mathrm{M}$, and $\mathrm{C} \cdot \mathrm{M}$ were the fixed effects and $\mathrm{P}$ and $\mathrm{A}$ the random effects. Results are presented as treatment means with a SEM, and significance was considered at $P<0.05$.

\section{RESULTS}

No interactions were observed between CLA and MP for milk or milk component variables (Table 2). Supplementation with CLA increased milk yield by $16 \%(P<$ 0.001), whereas feeding the high compared with low MP increased milk yield by $18 \%(P<0.001)$. In contrast, CLA supplementation reduced milk fat percentage and yield by 33 and $24 \%$, respectively. The MP level in the diet had no effect on milk fat content although milk fat yield was increased by $15 \%(P<0.001)$ in ewes receiving the high MP diet. Milk protein content was reduced by $3 \%(P<0.05)$ following CLA supplementation, but dietary MP level had no effect $(P>0.05)$. In contrast, CLA supplementation and feeding the high MP level increased milk protein yield by 13 and 19\%, respectively $(P<0.001)$. Additionally, CLA supplementation and feeding the high MP diet increased milk lactose yield by 17 and $16 \%$, respectively $(P<0.001)$.

An interaction $(P<0.05)$ was observed between CLA supplementation and dietary MP level on BW and BCS; when ewes were fed the low but not the high 
Table 2. Performance of ewes fed low or high MP diets either supplemented or unsupplemented with conjugated linoleic acid (CLA) ${ }^{1}$

\begin{tabular}{|c|c|c|c|c|c|c|c|c|}
\hline \multirow[b]{3}{*}{ Variable } & \multicolumn{4}{|c|}{ Treatment } & \multirow[b]{3}{*}{ SEM } & & & \\
\hline & \multicolumn{2}{|c|}{ Low MP } & \multicolumn{2}{|c|}{ High MP } & & \multicolumn{3}{|c|}{ Significance $^{2}$} \\
\hline & $-\mathrm{CLA}$ & + CLA & - CLA & + CLA & & M & $\mathrm{C}$ & $\mathrm{M} \times \mathrm{C}$ \\
\hline Intake, $\mathrm{kg}$ of $\mathrm{DM} / \mathrm{d}$ & 1.8 & 1.8 & 1.8 & 1.8 & & & & \\
\hline Milk yield, g/d & 670 & 780 & 787 & 917 & 27.5 & $<0.001$ & $<0.001$ & 0.73 \\
\hline \multicolumn{9}{|l|}{ Milk fat } \\
\hline$\%$ & 7.50 & 4.93 & 7.13 & 4.87 & 0.146 & 0.15 & $<0.001$ & 0.29 \\
\hline \multirow{2}{*}{\multicolumn{9}{|c|}{ Milk protein }} \\
\hline & & & & & & & & \\
\hline$\%$ & 5.12 & 4.92 & 5.10 & 4.99 & 0.064 & 0.69 & 0.024 & 0.49 \\
\hline \multirow{2}{*}{\multicolumn{9}{|c|}{ Milk lactose }} \\
\hline & & & & & & & & \\
\hline$\%$ & 4.60 & 4.59 & 4.50 & 4.58 & 0.047 & 0.27 & 0.48 & 0.28 \\
\hline $\mathrm{g} / \mathrm{d}$ & 31.0 & 35.8 & 35.6 & 42.1 & 1.37 & $<0.001$ & $<0.001$ & 0.56 \\
\hline $\mathrm{BW}, \mathrm{kg}$ & 60.9 & 62.0 & 61.4 & 60.9 & 0.35 & 0.44 & 0.32 & 0.029 \\
\hline BW change, $\mathrm{kg} / \mathrm{d}$ & 0.03 & 0.08 & 0.08 & 0.05 & 0.019 & 0.83 & 0.68 & 0.066 \\
\hline $\mathrm{BCS}^{3}$ & 2.13 & 2.16 & 2.27 & 2.09 & 0.047 & 0.45 & 0.12 & 0.036 \\
\hline BCS change, units/d & -0.006 & -0.006 & -0.001 & -0.006 & 0.0021 & 0.20 & 0.31 & 0.38 \\
\hline $\mathrm{EBAL},{ }^{4} \mathrm{Mcal} / \mathrm{d}$ & 1.5 & 1.6 & 1.3 & 1.4 & 0.04 & $<0.001$ & 0.005 & 0.94 \\
\hline \multicolumn{9}{|c|}{ Mean plasma concentrations } \\
\hline Urea, mmol/L & 5.8 & 5.3 & 9.0 & 7.6 & 0.31 & $<0.001$ & 0.005 & 0.160 \\
\hline $\mathrm{BHBA}, \mathrm{mmol} / \mathrm{L}$ & 0.45 & 0.40 & 0.45 & 0.43 & 0.020 & 0.67 & 0.093 & 0.42 \\
\hline Glucose, $\mathrm{mmol} / \mathrm{L}$ & 3.16 & 3.14 & 3.08 & 3.21 & 0.071 & 0.18 & 0.92 & 0.17 \\
\hline
\end{tabular}

${ }^{1}$ Values represent an average of $5 \mathrm{~d}$ of sampling of each period.

${ }^{2} P$-values; $\mathrm{M}=$ main effect of $\mathrm{MP}$ level, $\mathrm{C}=$ main effect of CLA, $\mathrm{M} \times \mathrm{C}=$ interaction between $\mathrm{MP}$ and CLA.

${ }^{3}$ Scale $0=$ thin to $5=$ fat (Russell et al., 1969).

${ }^{4}$ Calculated according to AFRC (1993) as ME intake (adjusted for feeding level) - (maintenance energy requirements + milk energy output).

dietary MP level, supplementation with CLA increased $\mathrm{BW}$ and BCS and tended $(P=0.07)$ to increase BW change, but BCS change was not affected $(P>0.05)$. The calculated energy balance was greater $(P<0.01)$ in ewes fed CLA or the low MP diets. Plasma urea concentrations were lower in ewes fed CLA $(P<0.01)$ or low MP $(P<0.001)$ throughout the day (Figure 1$)$. A trend $(P=0.09)$ was observed for plasma BHBA concentrations to be lower in ewes when supplemented with CLA but dietary treatment had no effect $(P>$ 0.05 ) on plasma glucose concentrations (Table 2).

Milk fat from ewes supplemented with CLA had a reduced proportion of both de novo synthesized FA $(<\mathrm{C} 16)$ and FA derived from de novo synthesis $(P<$ 0.001 ) and uptake from the circulatory system (C16; $P<0.05)$ as well as a greater proportion of long-chain FA $(>$ C16; $P<0.001 ;$ Table 3$)$. Similarly, ewes fed the high MP diets had reduced concentrations of both $<\mathrm{C} 16(P=0.05)$ and $\mathrm{C} 16(P<0.001)$ and an increase in $>$ C16 FA $(P<0.001)$ compared with those fed the low MP diet. Compared with the unsupplemented ewes, those supplemented with CLA had increased $(P<0.01)$ milk fat contents of C18:1 trans-10, C18:1 trans-11, C18:1 trans-12, C18:1 cis-9, trans-10, cis-12 CLA, cis-9,trans-11 CLA, and C20:0. The transfer of trans-10, cis-12 CLA from the dietary supplement to secretion in milk fat was similar between CLA treatments and averaged $1.54 \pm 0.07 \%$ (mean $\pm \mathrm{SD}$ ). The content of trans-10,cis-12 CLA in milk fat was not affected $(P$ $>0.05)$ by dietary MP level but contents of C18:0, C18:1 trans-10, C18:1 trans-11, C18:1 trans- $12, \mathrm{C} 18: 1$ cis-9, C18:2 cis-9,cis-12, cis-9,trans-11 CLA, and C20:0 were increased $(P<0.05)$ in ewes when fed the high compared with the low MP diet. In contrast, ewes fed

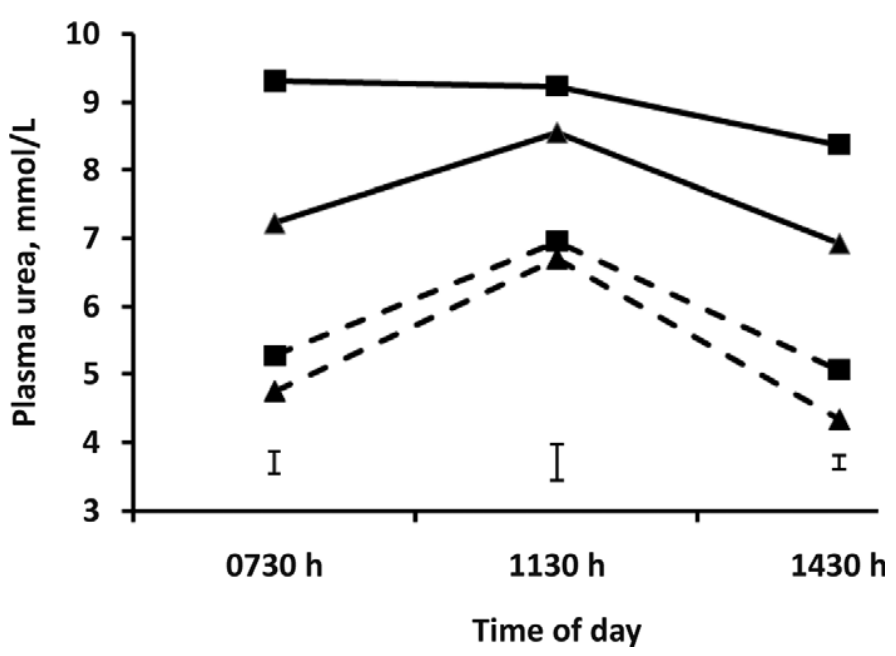

Figure 1. Plasma urea concentrations in ewes fed low (- -) or

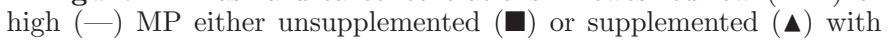
conjugated linoleic acid. Error bars indicate SEM. 
Table 3. Fatty acid composition of milk fat from ewes fed low or high MP diets either supplemented or unsupplemented with conjugated linoleic acid $(\mathrm{CLA})^{1}$

\begin{tabular}{|c|c|c|c|c|c|c|c|c|}
\hline \multirow{3}{*}{$\begin{array}{l}\text { Fatty acid, } \\
\mathrm{g} / 100 \mathrm{~g}\end{array}$} & \multicolumn{4}{|c|}{ Treatment } & \multirow[b]{3}{*}{ SEM } & \multirow{2}{*}{\multicolumn{3}{|c|}{ Significance $^{2}$}} \\
\hline & \multicolumn{2}{|c|}{ Low MP } & \multicolumn{2}{|c|}{ High MP } & & & & \\
\hline & - CLA & + CLA & - CLA & + CLA & & M & $\mathrm{C}$ & $\mathrm{M} \times \mathrm{C}$ \\
\hline 4:0 & 2.81 & 2.84 & 2.89 & 2.91 & 0.058 & 0.22 & 0.69 & 0.96 \\
\hline 6:0 & 1.94 & 1.19 & 1.93 & 1.09 & 0.056 & 0.32 & $<0.001$ & 0.42 \\
\hline $8: 0$ & 1.69 & 0.88 & 1.65 & 0.77 & 0.066 & 0.28 & $<0.001$ & 0.59 \\
\hline 10:0 & 5.38 & 2.79 & 4.96 & 2.46 & 0.240 & 0.14 & $<0.001$ & 0.86 \\
\hline $12: 0$ & 3.19 & 2.26 & 2.85 & 2.13 & 0.121 & 0.072 & $<0.001$ & 0.41 \\
\hline 14:0 & 9.72 & 9.30 & 8.96 & 8.80 & 0.211 & 0.006 & 0.18 & 0.55 \\
\hline 14:1 cis-9 & 0.14 & 0.12 & 0.13 & 0.10 & 0.010 & 0.39 & 0.013 & 0.49 \\
\hline $15: 0$ & 1.21 & 1.17 & 1.17 & 1.12 & 0.028 & 0.12 & 0.09 & 0.84 \\
\hline 16:0 & 33.7 & 33.1 & 32.1 & 31.4 & 0.274 & $<0.001$ & 0.022 & 0.87 \\
\hline $16: 1$ cis-9 & 1.19 & 1.11 & 1.17 & 1.00 & 0.052 & 0.19 & 0.025 & 0.43 \\
\hline $17: 0$ & 0.67 & 0.66 & 0.64 & 0.65 & 0.012 & 0.069 & 0.91 & 0.45 \\
\hline 18:0 & 9.2 & 12.4 & 10.1 & 14.0 & 0.325 & $<0.001$ & $<0.001$ & 0.30 \\
\hline 18:1 trans -9 & 0.09 & 0.12 & 0.09 & 0.12 & 0.011 & 0.96 & 0.052 & 0.92 \\
\hline $18: 1$ trans -10 & 0.62 & 0.87 & 0.65 & 0.99 & 0.031 & 0.029 & $<0.001$ & 0.15 \\
\hline 18:1 trans- 11 & 0.84 & 1.09 & 1.07 & 1.49 & 0.051 & $<0.001$ & $<0.001$ & 0.18 \\
\hline 18:1 trans -12 & 0.42 & 0.49 & 0.44 & 0.53 & 0.013 & 0.026 & $<0.001$ & 0.45 \\
\hline $18: 1$ cis-9 & 17.4 & 19.3 & 19.0 & 19.6 & 0.37 & 0.012 & 0.003 & 0.09 \\
\hline $18: 2$ cis -9, cis -12 & 1.75 & 1.72 & 2.14 & 2.05 & 0.052 & $<0.001$ & 0.26 & 0.60 \\
\hline $18: 2$ cis -9, trans $-11^{3}$ & 0.22 & 0.39 & 0.31 & 0.44 & 0.016 & $<0.001$ & $<0.001$ & 0.30 \\
\hline 18:2 trans -10, cis -12 & $<0.01$ & 0.08 & $<0.01$ & 0.10 & 0.006 & 0.20 & $<0.001$ & 0.13 \\
\hline $18: 3$ cis -9, cis -12, cis- 15 & 0.30 & 0.27 & 0.26 & 0.25 & 0.010 & 0.004 & 0.09 & 0.25 \\
\hline 20:0 & 0.13 & 0.15 & 0.13 & 0.16 & 0.003 & 0.020 & $<0.001$ & 0.62 \\
\hline $22: 0$ & 0.07 & 0.07 & 0.07 & 0.13 & 0.031 & 0.26 & 0.39 & 0.37 \\
\hline Remaining & 7.05 & 7.30 & 7.00 & 7.35 & 0.305 & 0.77 & 0.36 & 0.86 \\
\hline \multicolumn{9}{|l|}{ Summation, g/100 g } \\
\hline$<16$ & 26.1 & 20.5 & 24.5 & 19.4 & 0.65 & 0.050 & $<0.001$ & 0.79 \\
\hline 16 and $16: 1$ & 34.9 & 34.2 & 33.3 & 32.4 & 0.29 & $<0.001$ & 0.013 & 0.77 \\
\hline$>16$ & 39.0 & 45.3 & 42.2 & 48.2 & 0.64 & $<0.001$ & $<0.001$ & 0.82 \\
\hline \multicolumn{9}{|l|}{ Desaturase index } \\
\hline $14: 1 /(14: 0+14: 1)$ & 0.014 & 0.012 & 0.014 & 0.011 & 0.001 & 0.74 & 0.016 & 0.24 \\
\hline $16: 1 /(16: 0+16: 1)$ & 0.033 & 0.032 & 0.034 & 0.030 & 0.001 & 0.73 & 0.054 & 0.32 \\
\hline $18: 1 /(18: 0+18: 1)$ & 0.66 & 0.61 & 0.65 & 0.58 & 0.007 & 0.06 & $<0.001$ & 0.01 \\
\hline $\begin{array}{l}\text { cis-9,trans-11 CLA/(18:1 } \\
\text { trans- } 11+\text { cis-9,trans-11 CLA) }\end{array}$ & 0.23 & 0.27 & 0.23 & 0.24 & 0.008 & 0.10 & 0.017 & 0.047 \\
\hline
\end{tabular}

${ }^{1}$ Values represent milk fatty acid profile on $\mathrm{d} 5$ of each sampling period.

${ }^{2} P$-values; $\mathrm{M}=$ main effect of $\mathrm{MP}$ level, $\mathrm{C}=$ main effect of $\mathrm{CLA}, \mathrm{M} \times \mathrm{C}=$ interaction between $\mathrm{MP}$ and CLA.

${ }^{3}$ Milk fat contains several additional isomers of CLA (cis/trans, cis/cis, and trans/trans) and these coelute under the analytical conditions used in the present study.

the low MP diet had higher $(P<0.05)$ milk fat contents of $\mathrm{C} 16: 0$ and $\mathrm{C} 18: 3$ cis-9,cis-12,cis-15. Desaturase indices of $\mathrm{C} 14: 1$ cis-9/C14:0+C14:1 cis-9 and C18:1 cis-9/C18:0+C18:1 cis-9 decreased in animals supplemented with CLA but dietary MP level had no effect (Table 3). Milk fat yield of all FA was reduced with the CLA treatment but the extent of the reduction varied according to source of the FA. When calculated on a molar basis, FA $<\mathrm{C} 16$ accounted for $51 \%$ of the decrease in total milk FA secretion and $\mathrm{C} 16$ and $>\mathrm{C} 16$ accounted for 33 and $16 \%$ of the decrease, respectively $(P<0.001)$, in ewes supplemented with CLA (Figure $2)$. Ewes fed the high MP diet compared with the low MP diet had increased milk yields of FA $<\mathrm{C} 16, \mathrm{C} 16$, and $>$ C16, with $<\mathrm{C} 16$ and C16 FA accounting for $45 \%$ of the increase and $>$ C16 FA accounting for $55 \%$ of the increase $(P<0.05)$.

\section{DISCUSSION}

As reviewed in the introduction, supplementing dairy cows with trans-10,cis-12 CLA when they are in negative EBAL in early lactation or when intake is restricted has been shown to increase milk and milk protein yield. We therefore restricted intake in the current study to $75 \%$ of ad libitum levels in an attempt to reflect this metabolic state in dairy ewes. Likewise, a milk and milk protein response to CLA has been observed in grazing dairy cows, a situation in which dietary energy supply is often restricted but MP supply is in excess. For this reason, we altered dietary MP levels to supply either a high (110\%) or low (93\%) level of requirement, although energy intake was still limiting. Supplementation with CLA in the current study increased milk and milk protein yields by 16 and $13 \%$, respectively. These 


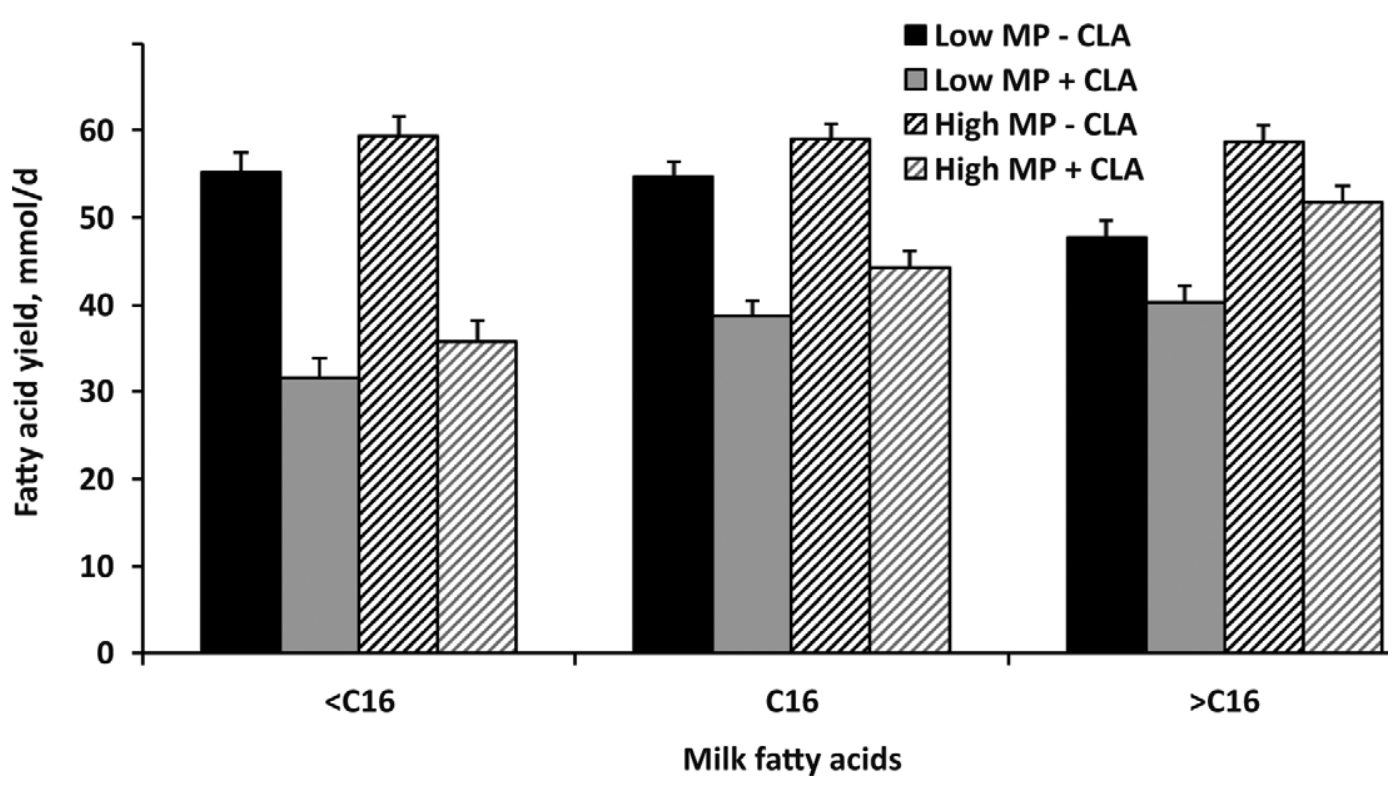

Figure 2. Daily fatty acid yield (mmol) in ewes fed low or high MP diets either unsupplemented or supplemented with conjugated linoleic acid (CLA). Values represent means of d 5 each sampling period. Standard error is indicated by bars over each column. For MP, $P=0.07$ for FA of $<\mathrm{C} 16$ and $P<0.01$ for FA of $\mathrm{C} 16$ and $>\mathrm{C} 16$. For CLA, $P<0.001$ for FA $<\mathrm{C} 16, \mathrm{C} 16$, and $>\mathrm{C} 16$.

values are greater than the 10 and $7 \%$ increase in milk and milk protein yield in ewes when fed ad libitum and supplemented the same CLA dose as used here $(2.4 \mathrm{~g} / \mathrm{d}$ of trans-10,cis-12 CLA; Lock et al., 2006) or the nonsignificant effect on milk yield when a low dose was used (1.5 g/d of trans-10,cis-12 CLA; Sinclair et al., 2010). It may be, therefore, that the milk yield response to trans-10,cis-12 CLA supplementation in dairy ewes is greater when animals have a restricted energy intake or are supplemented at a higher level of CLA. In contrast, supplementing ewes with $2.4 \mathrm{~g} / \mathrm{d}$ of trans-10, cis-12 CLA when intake was restricted resulted in no milk or milk protein yield response (Sinclair et al., 2007), although the level of energy restriction was less pronounced than in the current study (5.0 and $6.7 \mathrm{Mcal} / \mathrm{d})$. Additionally, CLA supplementation resulted in a more positive EBAL in the previous study (Sinclair et al., 2007).

The reduction in energy required for milk fat synthesis due to CLA supplementation provides an alternative source of ME to the lactating animal that may be used to increase milk production (Newbold, 1994). For ewes receiving the low MP diet, approximately $28 \%$ of the energy spared by the CLA-induced reduction in milk fat output was partitioned to support an increase in milk protein and lactose yields; this value increased to $44 \%$ for ewes receiving the high MP diet. We suggest, therefore, that the positive effect of CLA in combination with MP on milk yield in the current study supports the hypothesis that, under energy-limiting situations, the energy spared from the CLA-induced reduction in milk fat synthesis may be partitioned to milk and milk protein yield.

In lactating dairy ewes (Cannas et al., 1998) and cows (Nocek and Russell, 1988; Hristov et al., 2004; Metcalf et al., 2008), an increase in dietary CP intake is associated with an increase in DMI, which consequently drives a greater milk and milk component yield. In the current study, intake was restricted and ewes were therefore unable to alter their intake in response to dietary MP supply. Despite this, milk yield and milk protein yield were increased by 18 and 19\%, respectively, when MP was increased. In a grazing situation where intake was unaffected by dietary CP level, Wilkinson et al. (2000) reported a marginal response to dietary MP supply in dairy ewes of $0.21 \mathrm{~g}$ of milk protein per $\mathrm{g}$ of additional MP intake. In the current study, the marginal response to increasing MP supply under conditions of limited ME supply was remarkably similar at $0.22 \mathrm{~g} / \mathrm{g}$, and very close to the theoretical $0.25 \mathrm{~g} / \mathrm{g}$ suggested for dairy cows by Webster (1992). Additionally, the milk and milk protein yield response to CLA and high MP supply were additive, such that the ewes fed the high MP diet + CLA had milk and milk protein yields 37 and $34 \%$ higher, respectively, than those fed the low MP diet - CLA.

The decline in milk fat output of both de novo synthesized and preformed FA $(<\mathrm{C} 16)$ in response to CLA supplementation is consistent with previous results in dairy ewes (Lock et al., 2006; Sinclair et al., 2007) and dairy cows (reviewed by Harvatine et al., 2009). When 
a similar lipid-encapsulated CLA source was fed to lactating ewes, both Sinclair et al. (2007) and Lock et al. (2006) reported increases in milk fat content of C18:1 trans-10, C18:1 trans-11, trans-10,cis-12 CLA, and cis9,trans-11 CLA. Trans FA are formed as intermediates in the biohydrogenation of polyunsaturated FA (Bauman and Griinari, 2003), so partial ruminal biohydrogenation of the CLA isomers in the supplement is a logical source for these increases.

In the current study, increasing dietary MP supply was also associated with an increase in the proportion of milk FA of $>\mathrm{C} 16$ (which represent those taken up by the mammary gland from the blood stream) and a decrease in the proportion of milk FA $<$ C16 (which are derived from de novo synthesis). The change in milk FA $>\mathrm{C} 16$ in the present study is consistent with that reported in dairy cows fed differing MP levels and at a restricted energy intake (de Veth et al., 2006). Increased dietary MP supply is associated with an increase in body fat mobilization (Robinson, 1987), which is consistent with the changes in milk FA proportions and yields observed here. Indeed, animals fed the high MP diets were calculated to be in a less positive EBAL, although the relatively short-term changeover design used in the current work may have prohibited determination of changes in body fat levels.

Consistent with studies that have monitored the effect of altering dietary MP supply on plasma urea concentrations (Cannas et al., 1998), ewes that received the high MP diet had mean plasma urea concentrations approximately $48 \%$ greater than those receiving the low MP diet. Plasma urea concentrations are a reflection of the combined effects of amino acid deamination and ammonia production in the rumen, and amino acid deamination and oxidation at the tissue level. As the high MP diet used in the current study was predicted to have a similar RDP content to the low MP diet, the elevated plasma urea concentrations in ewes receiving this treatment may be a reflection of a greater tissue amino acid deamination. Of particular interest was the decreased plasma urea concentration in ewes when supplemented with CLA, a response that was inversely related to the increase in milk protein yield. We suggest, therefore, that supplementation with CLA resulted in a more efficient use of dietary amino acids as a consequence of the greater energy supply that was spared due to MFD. Supplementation with CLA has been shown to have little effect on insulin sensitivity and plasma glucose concentrations, even during extensive MFD (e.g., Baumgard et al., 2002; de Veth et al., 2006), and plasma glucose concentrations were not altered by CLA supplementation in the current study. Plasma BHBA concentrations, which are not under homeostatic control, tended $(P<0.1)$ to be lower in ewes receiving CLA supplementation, supporting the observation that ewes on this treatment were in a more positive EBAL.

\section{CONCLUSIONS}

Dietary addition of a rumen-protected CLA supplement that contained trans-10,cis-12 CLA to dairy ewes when fed at a restricted level decreased milk fat synthesis, and the energy spared resulted in an increase in the yields of milk and milk protein. This effect was additive to the increase in the yields of milk and milk protein obtained through increased dietary MP supply.

\section{ACKNOWLEDGMENTS}

The technical support of D. Ferguson, G. Vince, and A. Ali and the assistance of T. Long, E. Suleiman, and F. Pottier at Harper Adams University College (Newport, UK) are gratefully acknowledged.

\section{REFERENCES}

Agricultural and Food Research Council. 1993. Energy and Protein Requirements of Ruminants. CAB International, Wallingford, UK.

Bauman, D. E., and J. M. Griinari. 2003. Nutritional regulation of milk fat synthesis. Annu. Rev. Nutr. 23:203-227.

Bauman, D. E., J. W. Perfield II, K. J. Harvatine, and L. H. Baumgard. 2008. Regulation of fat synthesis by conjugated linoleic acid: Lactation and the ruminant model. J. Nutr. 138:403-409.

Baumgard, L. H., B. A. Corl, D. A. Dwyer, and D. E. Bauman. 2002 Effect of conjugated linoleic acid (CLA) on tissue response to homeostatic signals and plasma variables associated with lipid metabolism in lactating dairy cows. J. Anim. Sci. 80:1285-1293.

Bernal-Santos, G., J. W. Perfield II, D. M. Barbano, D. E. Bauman, and T. R. Overton. 2003. Production responses of dairy cows to dietary supplementation with conjugated linoleic acid (CLA) during the transition period and early lactation. J. Dairy Sci. $86: 3218-3228$.

Cannas, A., A. Pes, R. Mancuso, B. Vordet, and A. Nudda. 1998. Effect of dietary energy and protein concentration on the concentration of milk urea nitrogen in dairy ewes. J. Dairy Sci. 81:499-508.

Chouinard, P. Y., L. Corneau, D. M. Barbano, L. E. Metzger, and D. E. Bauman. 1999. Conjugated linoleic acids alter milk fatty acid composition and inhibit milk fat secretion in dairy cows. J. Nutr. 129:1579-1584.

Christie, W. W. 1982. A simple procedure for the rapid transmethylation of glycerolipids and cholesterol esters. J. Lipid Res. 23:1072-1075.

de Veth, M. J., E. Castañeda-Gutierrez, D. A. Dwyer, A. M. Pfeiffer, D. Putnam, and D. E. Bauman. 2006. Response to conjugated linoleic acid in dairy cows differing in energy and protein status. J. Dairy Sci. 89:4620-4631.

de Veth, M. J., S. K. Gulati, N. D. Luchini, and D. E. Bauman. 2005. Comparison of calcium salts and formaldehyde-protected conjugated linoleic acid in inducing milk fat depression. J. Dairy Sci. $88: 1685-1693$.

Hara, A., and N. S. Radin. 1978. Lipid extraction of tissues with a low-toxicity solvent. Anal. Biochem. 90:420-426.

Harvatine, K. J., Y. R. Boisclair, and D. E. Bauman. 2009. Recent advances in the regulation of milk fat synthesis. Animal 3:40-54.

Hristov, A. N., W. J. Price, and B. Shafii. 2004. A meta-analysis examining the relationship among dietary factors, dry matter intake, and milk and milk protein yield in dairy cows. J. Dairy Sci. $87: 2184-2196$. 
Husvéth, F., E. Galamb, T. Gaál, K. Dublecz, L. Wágner, and L. Pál. 2010. Milk production, milk composition, liver lipid contents and C18 fatty acid composition of milk and liver lipids in Awassi ewes fed a diet supplemented with protected cis-9, trans-11 and trans-10, cis-12 conjugated linoleic (CLA) isomers. Small Rumin. Res. 94:25-31

Kay, J. K., J. R. Roche, C. E. Moore, and L. H. Baumgard. 2006. Effects of dietary conjugated linoleic acid production and metabolic parameters in transition dairy cows grazing fresh pasture. J. Dairy Res. 73:367-377.

Kolver, E. S., and L. D. Muller. 1998. Performance and nutrient intake of high producing Holstein cows consuming pasture or a total mixed ration. J. Dairy Sci. 81:1403-1411.

Lock, A. L., B. M. Teles, J. W. Perfield, D. E. Bauman, and L. A. Sinclair. 2006. A conjugated linoleic acid supplement containing trans-10, cis-12 reduces milk fat synthesis in lactating sheep. J. Dairy Sci. 89:1525-1532.

Loor, J. J., K. A. Ueda, A. Ferlay, Y. Chilliard, and M. Doreau. 2004. Biohydrogenation, duodenal flow, and intestinal digestibility of trans fatty acids and conjugated linoleic acids in response to dietary forage: concentrate ratio and linseed oil in dairy cows. J. Dairy Sci. 87:2472-2485.

Mackle, T. R., J. K. Kay, M. J. Auldist, A. K. H. McGibbon, B. A. Philpott, L. H. Baumgard, and D. E. Bauman. 2003. Effects of abomasal infusion of conjugated linoleic acid on milk fat concentration and yield from pasture-fed dairy cows. J. Dairy Sci. 86:644-652.

Medeiros, S. R., D. E. Oliveira, L. J. M. Aroeira, M. A. McGuire, D. E. Bauman, and D. P. D. Lanna. 2010. Effects of dietary supplementation of rumen protected conjugated linoleic acid to grazing cows in early lactation. J. Dairy Sci. 93:1126-1137.

Metcalf, J. A., R. J. Mansbridge, J. S. Blake, J. D. Oldham, and J. R. Newbold. 2008. The efficiency of conversion of metabolisable protein into milk true protein over a range of metabolisable protein intakes. Animal 2:1193-1202.

Newbold, J. R. 1994. Practical applications of the metabolisable protein system. Pages 231-264 in Recent Advances in Animal Nutrition. P. C. Garnsworthy and D. J. A. Cole, ed. Nottingham University Press, Nottingham, UK.

Nocek, J. E., and J. B. Russell. 1988. Protein and energy as an integrated system-Relationship of ruminal protein and carbohydrate availability to microbial synthesis and milk production. J. Dairy Sci. 71:2070-2107.

Perfield, J. W., A. L. Lock, J. M. Griinari, A. Saebo, P. Delmonte, D. A. Dwyer, and D. E. Bauman. 2007. Trans-9, cis-11 conjugated linoleic acid reduces milk fat synthesis in lactating dairy cows. J. Dairy Sci. 90:2211-2218

Robinson, J. J. 1987. Energy and protein requirements of the ewe. Pages 187-204 in Recent Advances in Animal Nutrition. W. Haresign and D. J. A. Cole, ed. Nottingham University Press, Nottingham, UK.

Russell, A. J. F., J. M. Doney, and R. G. Gunn. 1969. Subjective assessment of body fat in live sheep. J. Agric. Sci. (Camb.) 72:351358 .

Saebø, A., P. C. Saebø, J. M. Griinari, and K. J. Shingfield. 2005. Effect of abomasal infusions of geometric isomers of 10,12 conjugated synthesis linoleic acid on milk fat in dairy cows. Lipids 40:823-832.

Schauff, D. J., J. H. Clark, and J. K. Drackley. 1992. Effects of feeding lactating dairy cows diets containing extruded soybeans and calcium salts of long-chain fatty acids. J. Dairy Sci. 75:3003-3019.

Sinclair, L. A., A. L. Lock, R. Early, and D. E. Bauman. 2007. Effects of trans-10, cis-12 conjugated linoleic acid on ovine milk fat synthesis and cheese properties. J. Dairy Sci. 90:3326-3335.

Sinclair, L. A., W. M. P. B. Weerasinghe, R. G. Wilkinson, M. J. de Veth, and D. E. Bauman. 2010. A supplement containing trans-10, cis-12 conjugated linoleic acid reduces milk fat yield but does not alter organ weight or body fat deposition in lactating ewes. J. Nutr. 140:1949-1955.

Sukhija, P. S., and D. L. Palmquist. 1988. Rapid method for determination of total fatty acid content and composition of feedstuffs and faeces. J. Agric. Food Chem. 36:1202-1206.

Webster, A. J. F. 1992. The metabolisable protein system for ruminants. Pages 93-110 in Recent Advances in Animal Nutrition. P. C. Garnsworthy and D. J. A. Cole, ed. Butterworths, London, UK.

Wilkinson, R. G., L. A. Sinclair, J. Powles, and C. M. Minter. 2000 Response of lactating ewes grazing grass to variations in effective rumen degradable protein and digestible undegradable protein supply from concentrate supplements. Anim. Sci. 71:369-379. 